\title{
O JULGAMENTO DOS RES 594.015 E 601.720 E A REVISÃO JURISPRUDENCIAL A RESPEITO DA LEGITIMIDADE PASSIVA DO IPTU NA HIPÓTESE DE POSSUIDOR SEM ANIMUS DOMINI
}

\author{
Ramon Rocha Santos ${ }^{1}$ \\ Suênio Walttemberg Gonçalves e Silva²
}

\begin{abstract}
RESUMO: Embora o Supremo Tribunal Federal tenha firmado entendimento no sentido de que o possuidor de bem imóvel sem animus domini não figura como contribuinte ou responsável tributário do IPTU, a premissa utilizada pelo pretório excelso no julgamento dos Recursos Extraordinários 594.015 e 601.720 pode representar uma mudança na maneira que o Tribunal interpreta o instituto. Com este escopo, o presente artigo pretende revisar os institutos que permeiam a matéria, com vias a compreender os limites das decisões judiciais dos recursos mencionados, bem como avaliar a consequência hermenêutica da eventual mudança de paradigma.
\end{abstract}

Palavras-chave: IPTU, legitimidade, passiva, animus domini, jurisprudência

\section{THE JUDGMENT OF THE SRS 594.015 AND 601.720 AND THE JURISPRUDENTIAL REVIEW REGARDING THE PASSIVE LEGITIMACY OF THE IPTU IN THE HYPOTHESIS OF POSSESSOR WITHOUT ANIMUS DOMINI}

\begin{abstract}
Although the Federal Supreme Court has ruled that the owner of immovable property without animus domini is not a taxpayer or responsible for IPTU, the premise used by the High Praetor in the judgment of Extraordinary Remedies 594.015 and 601.720 may represent a change in the way which the Court interprets the institute. With this scope, this article intends to review the institutes that permeate the matter, with a view to understanding the limits of the judicial decisions of the mentioned resources, as well as to evaluate the hermeneutical consequence of the eventual paradigm shift.
\end{abstract}

Keywords: IPTU, legitimacy, passive, animus domini, jurisprudence.

\footnotetext{
${ }^{1}$ Doutorando em Direito pela Universidade Federal da Bahia (UFBA). Mestre em Direito pela Universidade Federal de Sergipe (UFS). Graduado em Direito pela Universidade Salvador (2003). Especialista em Direito Tributário pelo Instituto Brasileiro de Estudos Tributários - IBET (2006). Especialista em Direito Constitucional pela Universidade Anhanguera-Uniderp (2011). Especialista em Direito Público pela Universidade AnhangueraUniderp (2012). Procurador do Município de Aracaju. Advogado. Auditor do Pleno do TJD/SE. Presidente do Tribunal de Justiça Desportiva do Futebol do Estado de Sergipe (TJD/SE). Conselheiro Seccional Suplente da OAB/SE. Membro da Comissão de Estudos Tributários da OAB/SE. Membro da Comissão de Esportes da OAB/SE. Professor Substituto do Departamento de Direito da Universidade Federal de Sergipe - UFS. Professor do curso de Direito da Faculdade Pio Décimo. Coordenador da Pós-Graduação em Direito Tributário da Universidade Tiradentes (UNIT).

${ }^{2}$ Especialista em Direito Tributário pela Universidade Tiradentes (2017). Graduado em Direito pela Universidade Tiradentes (2015). Advogado. Professor do curso de Pós-Graduação em Direito Tributário da Universidade Tiradentes. Membro do MAC da Academia Sergipana de Letras (ASL).
} 


\section{INTRODUÇÃO}

O art. 32 do Código Tributário Nacional define o IPTU como o imposto, de competência dos Municípios, sobre a propriedade predial e territorial urbana, cujo fato gerador é a propriedade, o domínio útil ou a posse de bem imóvel por natureza ou por acessão física, como definido na lei civil, localizado na zona urbana do Município.

Ao tratar da hipótese de incidência tributária de tal imposto, mais especificamente quanto à sua pertinência subjetiva, os manuais costumam definir que o possuidor do bem imóvel contribuinte do IPTU é aquele que, a despeito de não possuir título de propriedade, possui o bem com ânimo de proprietário.

Isto decorre, além da interpretação dada à regra-matriz de incidência, em razão de aspectos cotidianos relevantes. São estes os critérios sobre os quais a doutrina discorre e a jurisprudência do Superior Tribunal de Justiça e do Supremo Tribunal Federal firmaram entendimento, no modo alhures declinado.

Ocorre que o Supremo Tribunal Federal, por ocasião do julgamento dos Recursos Extraordinários $n^{\circ} 594.015$ e 601.720, limitando a aplicabilidade da imunidade tributária recíproca, consignou que a empresa privada arrendatária de imóvel público, quando seja ela exploradora de atividade econômica com fins lucrativos, é contribuinte de IPTU.

Ao fazê-lo, a Suprema Corte parece rever seu posicionamento classicamente firmado, já que o ente privado arrendatário ou concessionário de bem público não é, segundo hermenêutica tradicional, seu proprietário, titular de domínio útil ou possuidor ad usucapionem.

É a respeito de tais circunstâncias (factuais e jurídicas) que o presente artigo científico pretende discutir, tanto do ponto de vista doutrinário/científico, quanto o alcance daquelas decisões judiciais, discorrendo ainda a respeito das eventuais consequências interpretativas, jurisprudenciais e práticas dos precedentes.

A pertinência científica do tema se revela na aparente controvérsia posta em debate, desafiando a hermenêutica tributária tradicional, debatendo suas premissas e, quiçá, revendo o modo que os tribunais interpretam a regra-matriz de incidência tributária.

A pertinência social do tema, por sua vez, se dá porque o seu trato científico pode representar, ainda que em tese, mudança na postura das administrações públicas municipais nas estratégias arrecadatórias e fiscalizatórias, aumentando o alcance da sujeição passiva de imposto da sua competência. 


\section{O JULGAMENTO DOS RES 594.015 E 601.720 E A REVISÃO JURISPRUDENCIAL A RESPEITO DA LEGITIMIDADE PASSIVA DO IPTU NA HIPÓTESE DE POSSUIDOR SEM \\ ANIMUS DOMINI}

Para obtenção dos objetivos perquiridos, pretende o presente trabalho se valer da denominada Metodologia de Análise de Decisões, que consiste na feitura, em primeiro momento, de uma pesquisa exploratória acerca da temática, com posterior recorte objetivo que, na hipótese, trata-se da controvérsia interpretativa já anteriormente denotada, e, ao fim, explorar tal dialética no recorte institucional referente ao Supremo Tribunal Federal, especificamente quanto aos julgados dos Recursos Extraordinários nº 594.015 e 601.720.

Assim, será explanado inicialmente a regra matriz de incidência tributária do IPTU, com destaque para a sujeição passiva e o entendimento firmado pelo STJ e STF a esse respeito. Depois, far-se-á alusão à imunidade tributária recíproca, matéria relevante discutida nos julgados que serão, após, analisados a partir do panorama factual que levou à persecução processual, com foco na premissa utilizada pelo Tribunal e como o paradigma estabelecido pode significar mudanças na revisão jurisprudencial.

\section{A REGRA-MATRIZ DE INCIDÊNCIA TRIBUTÁRIA DO IPTU}

O Imposto incidente sobre a Propriedade Predial e Territorial Urbana - IPTU está previsto expressamente no art. 156, Inciso I da Constituição Federal de 1988 como de competência dos municípios.

Art. 156. Compete aos Municípios instituir impostos sobre:

I - propriedade predial e territorial urbana;

No plano infraconstitucional, encontra previsão no art. 32 do Código Tributário Nacional, que traz sua materialidade como sendo a propriedade, o domínio útil ou a posse de imóvel localizada na zona urbana do Município a que se refira.

Art. 32. O imposto, de competência dos Municípios, sobre a propriedade predial e territorial urbana tem como fato gerador a propriedade, o domínio útil ou a posse de bem imóvel por natureza ou por acessão física, como definido na lei civil, localizado na zona urbana do Município. 
Ao idealizar a chamada "regra-matriz de incidência tributária”3, o professor PAULO DE BARROS CARVALHO dá uma imensa contribuição aos operadores do Direito, na medida em que permite que seja dissecada a molécula normativa hipotético-condicional em partículas atômicas essenciais - denominadas pelo renomado professor de "critérios” ou "aspectos" estabelecendo a relação entre o antecedente e o consequente normativo.

Tomando por base este poderoso instrumento de análise lógico-jurídica da norma de incidência tributária, é possível identificar cada um dos critérios constantes do "descritor" (antecedente) e do "prescritor” (consequente) da norma jurídica tributária relativa ao IPTU dos mais de 5.500 municípios pátrios.

$\mathrm{Na}$ formulação da regra-matriz de incidência tributária, PAULO DE BARROS CARVALHO identifica a existência de três critérios no antecedente normativo (critério material, critério espacial e critério temporal) e dois critérios no consequente normativo (critério pessoal e critério quantitativo), sendo que cada um dos critérios constantes do prescritor é composto por dois elementos. O critério pessoal compreende o sujeito ativo e o sujeito passivo da obrigação tributária; já o critério quantitativo compreende a base de cálculo e a alíquota.

O critério material é o núcleo do fato gerador. Corresponde a uma situação definida em lei como necessária à sua ocorrência. É sempre um fato, uma conduta, identificada por um verbo - no infinitivo - acrescido de um complemento.

De acordo com Hugo DE BRITO MACHADO:

Ainda que se trate de um ato jurídico, no sentido dessa expressão no Direito Civil, o fato gerador da obrigação tributária há de ser sempre considerado como fato. Isto é importante para a compreensão da assertiva pela qual a capacidade tributária passiva independe da capacidade jurídica das pessoas naturais. ${ }^{4}$

O critério espacial refere-se ao local em que se considera ocorrido o fato gerador, ou seja, é o território no qual, ocorrida a situação descrita no aspecto material, surge a obrigação tributária. Via de regra, o aspecto espacial coincide com o território do ente tributante.

Conforme preleciona AIRES FERDINANDO BARRETO:

\footnotetext{
${ }^{3}$ CARVALHO, Paulo de Barros. Curso de Direito Tributário. 23. ed. São Paulo: Saraiva, 2011, p. 295.

${ }^{4}$ MACHADO, Hugo de Brito. Curso de Direito Tributário. 33a ed. São Paulo: Malheiros, 2012, p. 129.
} 
o aspecto espacial comporta duas vertentes: a) uma, genérica, que se confunde com o próprio âmbito territorial de validade da lei editada pelo ente tributante, que não pode ser ampliado por iniciativa do legislador municipal (embora possa ser reduzido), dadas as injunções das normas constitucionais que outorgam as competências e das esferas de atuação ou atribuições de cada ente federativo e dos Municípios; b) a segunda, específica, diz respeito à conexão do fato tributário, materialmente considerado, com uma determinada circunstância de lugar, nos termos da lei. ${ }^{5}$

O critério temporal corresponde ao momento em que deve ser considerado ocorrido o fato gerador. Nas lições de GERALDO ATALIBA:

A lei continente da h.i. tributária traz a indicação das circunstâncias de tempo, importantes para a configuração dos fatos imponíveis. Esta indicação pode ser implícita ou explícita. Na maioria das vezes, é simplesmente implícita. ${ }^{6}$

O critério pessoal diz respeito aos sujeitos ativo (ente tributante) e passivo (contribuinte ou responsável) da relação jurídica tributária.

Por fim, o critério quantitativo, também chamado de critério valorativo, refere-se às duas grandezas dimensionais do fato gerador (base de cálculo e alíquota), por intermédio do qual se estabelece o quantum debeatur da obrigação tributária.

De acordo com RicARDo MARIZ DE OliveIRA, “a base de cálculo é a quantidade de moeda pela qual se expressa o fato gerador, para receber a aplicação da respectiva alíquota e se determinar o montante do respectivo tributo." 7

Compreendidos todos os critérios que integram a regra-matriz de incidência tributária, podemos agora identificar cada um dos aspectos relacionados ao IPTU.

\footnotetext{
${ }^{5}$ BARRETO, Aires Fernandino. ISS - Alguns limites constitucionais do critério espacial. Revista Dialética de Direito Tributário. São Paulo, n. 208, p. 7-14, jun.2014, p. 7.

${ }^{6}$ ATALIBA, Geraldo. Hipótese de incidência tributária. São Paulo: Malheiros, 2005, p. 94.

${ }^{7}$ OLIVEIRA, Ricardo Mariz de. Fundamentos do Imposto de Renda. São Paulo: Quartier Latin, 2008, p. 395.
} 
O aspecto material, extraído das previsões contidas no art. 156, Inciso I do texto constitucional e art. 32 do Código Tributário Nacional - CTN, corresponde à propriedade, à posse e ao domínio útil de bem imóvel.

Art. 32. O imposto, de competência dos Municípios, sobre a propriedade predial e territorial urbana tem como fato gerador a propriedade, o domínio útil ou a posse de bem imóvel por natureza ou por acessão física, como definido na lei civil, localizado na zona urbana do Município.

O aspecto espacial, na dicção do art. 32 do CTN, é a zona urbana do município em que se encontra situado o imóvel, assim definida em lei municipal e, desde que presentes pelo menos dois dos melhoramentos previstos no $\S 1^{\circ}$ do sobredito dispositivo legal.
Art. 32. (...)
$\S 1^{\circ}$ Para os efeitos deste imposto, entende-se como zona urbana a definida em lei municipal; observado o requisito mínimo da existência de melhoramentos indicados em pelo menos 2 (dois) dos incisos seguintes, construídos ou mantidos pelo Poder Público:
I - meio-fio ou calçamento, com canalização de águas pluviais;
II - abastecimento de água;
III - sistema de esgotos sanitários;
IV - rede de iluminação pública, com ou sem posteamento para distribuição domiciliar;
V - escola primária ou posto de saúde a uma distância máxima de 3 (três) quilômetros do imóvel considerado.

Em se tratando de um imposto cujo fato gerador é continuado, a sua realização não ocorre em uma determinada unidade temporal, protraindo-se pelo período de um ano (respectivo exercício). Assim, é necessário, por uma ficção jurídica, realizar um corte temporal para identificar o referido aspecto, que corresponde à data identificada na respectiva lei municipal, sendo certo ainda que, na omissão legislativa, o aspecto temporal corresponde ao "primeiro dia de cada ano”, , conforme já teve a oportunidade de decidir o STJ.

Com relação ao aspecto pessoal, o sujeito ativo é o município onde se localiza o imóvel; já o sujeito passivo, por expressa previsão constante no art. 34 do CTN, é o proprietário do imóvel, o titular do seu domínio útil ou o seu possuidor a qualquer título. ${ }^{9}$

\footnotetext{
${ }^{8}$ STJ. REsp 1.434.570, Rel. Min. Napoleão Nunes Maia Filho, DJ 27.02.2014.

${ }^{9}$ De acordo com o entendimento pacífico no âmbito tanto do STF (RE 451.152-RJ) quanto do STJ (REsp 1.091.198), a posse apta a gerar a obrigação tributária é aquela qualificada pelo animus domini, ou seja, a que
} 


\section{O JULGAMENTO DOS RES 594.015 E 601.720 E A REVISÃO JURISPRUDENCIAL A RESPEITO DA LEGITIMIDADE PASSIVA DO IPTU NA HIPÓTESE DE POSSUIDOR SEM \\ ANIMUS DOMINI}

Art. 34. Contribuinte do imposto é o proprietário do imóvel, o titular do seu domínio útil, ou o seu possuidor a qualquer título.

Por fim, em relação ao aspecto quantitativo, temos que a base de cálculo, na forma que prevê o art. 33 do CTN, é o valor venal do imóvel; já a alíquota será aquela definida na respectiva lei ordinária de cada um dos municípios a que se refira.

Interessa-nos, aqui, em especial, a análise mais aprofundada de um dos elementos integrantes do critério pessoal - o sujeito passivo - e a sua intrínseca relação com o critério material do antecedente normativo.

\section{SUJEIÇÃO PASSIVA DO IPTU}

Traçada a regra-matriz de incidência tributária do IPTU, passemos à análise mais detalhada do seu aspecto pessoal, mais especificamente do sujeito passivo. Como visto, o art. 34 do CTN preceitua que o contribuinte do IPTU é o proprietário do imóvel, o titular do seu domínio útil ou o seu possuidor a qualquer título.

Registre-se, desde já, que a Constituição Federal de 1988 refere-se tão somente ao “proprietário”, sendo que o “titular do domínio útil” e o “possuidor a qualquer título” estão expressos apenas no Código Tributário Nacional.

Proprietário é aquele que tem a propriedade do imóvel e, portanto, a faculdade de usar, gozar e dispor do bem imóvel. No Brasil, por expressa previsão legal, a aquisição da propriedade imobiliária ocorre através do registro translativo no Registro Geral de Imóveis.

O titular do domínio útil, por sua vez, é aquele que mantém um regime de enfiteuse em relação ao imóvel (o enfiteuta). Cumpre registrar aqui que caso haja uma imunidade do “nu proprietário” (o detentor indireto do imóvel), a mesma não é aproveitada também pelo enfiteuta, na jurisprudência pacífica do STJ ${ }^{10}$.

efetivamente esteja em vias de ser transformada em propriedade, seja por meio da promessa de compra e venda, seja pela posse ad usucapionem.

${ }^{10}$ STJ. REsp 267.099, Rel. Min. Eliana Calmon, DJ 27.05.2002. 
Já o possuidor é aquele que exerce uma das prerrogativas inerentes à propriedade e possui o chamado animus domini, ou seja, a vontade de ter o bem como seu (posse ad usucapionem).

\section{O ENTENDIMENTO FIRMADO PELO STJ, NA HIPÓTESE DE POSSUIDOR SEM ANIMUS DOMINI}

A jurisprudência do STJ em torno do art. 34 do Código Tributário Nacional sempre foi no sentido de que a responsabilidade pelo pagamento do IPTU é do proprietário, somente incidindo sobre o possuidor quando este possuir o chamado animus domini.

Dessa forma, em relação ao locatário, arrendante e comodatário, por possuírem somente a posse direta do bem e não tendo a possibilidade de transferir, locar ou ceder a terceiros, sempre entendeu o STJ que não podem ser considerados como contribuintes do IPTU.

TRIBUTÁRIO - IPTU - CONTRIBUINTE - POSSUIDOR - ART. 34 DO CTN.

1. O IPTU é imposto que tem como contribuinte o proprietário ou o possuidor por direito real que exerce a posse com animus definitivo art. 34 do CTN.

2. O comodatário é possuidor por relação de direito pessoal e, como tal, não é contribuinte do IPTU do imóvel que ocupa.

3. Não sendo contribuinte o possuidor e confundindo-se, no Município, as posições de proprietário do imóvel e de sujeito ativo para a cobrança do IPTU, resulta indevido o tributo.

4. Recurso especial improvido. ${ }^{11}$

Ainda de acordo com o entendimento do STJ, o cessionário do direito real de uso também não é contribuinte do IPTU por ostentar a condição de possuidor por direito pessoal.

TRIBUTÁRIO. IPTU. CONTRIBUINTE. POSSUIDOR POR RELAÇÃO DE DIREITO PESSOAL. ART. 34 DO CTN.

1. O IPTU é imposto que tem como contribuinte o proprietário ou o possuidor por direito real, que exerce a posse com animus domini.

2. O cessionário do direito de uso é possuidor por relação de direito pessoal

e, como tal, não é contribuinte do IPTU do imóvel que ocupa.

3. Recurso especial improvido. ${ }^{12}$

${ }^{11}$ STJ. REsp 325.489, Rel. Min. Eliana Calmon, DJ 24.02.2003. 


\section{O JULGAMENTO DOS RES 594.015 E 601.720 E A REVISÃO JURISPRUDENCIAL A RESPEITO DA LEGITIMIDADE PASSIVA DO IPTU NA HIPÓTESE DE POSSUIDOR SEM \\ ANIMUS DOMINI}

Na servidão de passagem, igualmente, já decidiu o STJ não haver base legal para a cobrança do IPTU de quem apenas se utiliza de servidão de passagem em imóvel alheio.

TRIBUTÁRIO - IMPOSTO SOBRE A PROPRIEDADE TERRITORIAL URBANA - SERVIDÃO DE PASSAGEM

1. Os arts. 32 e 34 do CTN definem, respectivamente, o fato gerador e o contribuinte do IPTU, contemplando a propriedade, a posse e o domínio útil.

2. Não há base legal para cobrança do IPTU de quem apenas se utiliza de servidão de passagem de imóvel alheio.

3. Recurso especial não provido ${ }^{13}$.

Apesar de admitir a possibilidade de o promitente comprador ser sujeito passível do IPTU, o fundamento utilizado pelo STJ é justamente o entendimento fixado na sistemática do recurso repetitivo de que o referido sujeito detém a posse com animus domini.

TRIBUTÁRIO. EXECUÇÃO FISCAL. IPTU. CONTRATO DE PROMESSA DE COMPRA E VENDA DE IMÓVEL. LEGITIMIDADE PASSIVA DO POSSUIDOR (PROMITENTE COMPRADOR) E DO PROPRIETÁRIO (PROMITENTE VENDEDOR).

1. Segundo o art. 34 do CTN, consideram-se contribuintes do IPTU o proprietário do imóvel, o titular do seu domínio útil ou o seu possuidor a qualquer título.

2. A jurisprudência desta Corte Superior é no sentido de que tanto o promitente comprador (possuidor a qualquer título) do imóvel quanto seu proprietário/promitente vendedor (aquele que tem a propriedade registrada no Registro de Imóveis) são contribuintes responsáveis pelo pagamento do IPTU.

(...)

4. Recurso especial provido. Acórdão sujeito ao regime do art. 543-C do CPC e da Resolução STJ 08/08. ${ }^{14}$

No âmbito do STF, o entendimento consolidado até então era o de que somente o possuidor com animus domini poderia ser sujeito passivo do IPTU, na forma cristalizada no julgamento do RE $451.152^{15}$.

Recurso Extraordinário. 2. IPTU. Imóvel da União destinado à exploração comercial. 3. Contrato de concessão de uso. Posse precária e desdobrada. 4. Impossibilidade de a recorrida figurar no pólo

12 STJ. REsp 685.316, Rel. Min. Castro Meira, DJ 18.04.2005.

${ }^{13}$ STJ. REsp 601.129, Rel. Min. Eliana Calmon, DJ 24.05.2004.

${ }^{14}$ STJ. REsp 1.110.551, Rel. Min. Mauro Campbell Marques, DJe 18.06.2009.

${ }^{15}$ STF. RE 451.152, Rel. Min. Gilmar Mendes, DJ 27.04.2007. 
passivo da obrigação tributária. Precedente. Recurso extraordinário a que se nega provimento.

\section{A IMUNIDADE TRIBUTÁRIA RECÍPROCA E O JULGAMENTO DOS RECURSOS EXTRAORDINÁRIOS N 594.015 E 601.720}

A imunidade recíproca é uma forma de expressão do princípio federativo, não se podendo conceber uma federação sem a referida imunidade, estando a regra imunizante protegida, inclusive, contra eventual emenda constitucional, na forma que preceitua o art. 60, $\S 4^{\circ}$, I da Constituição Federal de 1988.

É da natureza do pacto federativo a imunidade recíproca dos entes que o compõem porque, sendo a federação uma macro associação de estados que se encontram no mesmo plano, não há que falar em relação de súdito para soberano, de poder superior a inferior, devendo a integração entre os entes políticos, como premissa para obtenção dos objetivos constitucionais, o marco da nova hermenêutica e do pós-positivismo, e não a sua segregação.

Dito isto, neste ponto, importa relatar o contexto e conteúdo dos julgados objeto de análise neste artigo, detalhando as decisões combatidas e, em síntese, a linha de argumentação adotada pelos recorrentes.

O Supremo Tribunal Federal reconheceu em 2011, com dois meses de diferença, a repercussão geral nos Recursos Extraordinários n ${ }^{\circ} 594.015$ e 601.720, que viriam a ser julgados juntos, em 06/04/2017.

O tema 385, associado ao primeiro recurso, versava sobre o "reconhecimento de imunidade tributária recíproca a sociedade de economia mista ocupante de bem público”. O tema 437, por sua vez, associado ao segundo, dizia “reconhecimento de imunidade tributária recíproca a empresa privada ocupante de bem público”.

No Recurso Extraordinário 594.015, de relatoria do Ministro Marco Aurélio, a Petrobrás recorreu de decisão da $14^{\mathrm{a}}$ Câmara de Direito Público do Tribunal de Justiça do Estado de São Paulo, que concluiu ser ela parte legítima para figurar como devedora do Imposto Predial e Territorial Urbano - IPTU incidente em imóvel localizado no Porto de Santos.

Isto porque, segundo a decisão recorrida, mesmo sendo mera arrendatária da Companhia Docas do Estado de São Paulo - CODESP de terreno em área portuária pertencente à União, a então recorrente não possuiria imunidade tributária recíproca, 


\section{O JULGAMENTO DOS RES 594.015 E 601.720 E A REVISÃO JURISPRUDENCIAL A RESPEITO DA LEGITIMIDADE PASSIVA DO IPTU NA HIPÓTESE DE POSSUIDOR SEM \\ ANIMUS DOMINI}

porquanto esse privilégio somente seria relativo à União, aos Estados, ao Distrito Federal e aos Municípios, e não às sociedades de economia mista exploradoras de atividade econômica.

Ainda segundo a Câmara, a condição de arrendatária não afastaria a obrigatoriedade do pagamento do tributo, haja vista o disposto no artigo 34 do Código Tributário Nacional, não se mostrando, portanto, tal alegação motivo suficiente para a aplicação da imunidade prevista no artigo 150, inciso VI, alínea “a”, da Constituição Federal.

A Empresa recorrente, por sua vez, sustentou a violação dos artigos 93, inciso IX, e 150, inciso VI, alínea “a”, da Carta Política, posto que o imóvel é bem de propriedade da União, afetado para a realização de atividades de utilidade pública e, assim, dada a peculiar natureza do uso por interesse público (abastecimento nacional de combustíveis), estaria alcançado pela imunidade constitucionalmente prevista.

Instada a se manifestar, a Procuradoria-Geral da República, em parecer, opinou pelo provimento do recurso, assinalando haver a jurisprudência do Supremo se consolidado no sentido de a imunidade recíproca alcançar sociedades de economia mista cuja atividade fim constitua monopólio da União.

No Recurso Extraordinário 601.720, de relatoria do Ministro Edson Fachin, o Município do Rio de Janeiro irresignou-se contra o acórdão proferido pelo Tribunal de Justiça do Estado homônimo, o qual reconheceu a imunidade tributária sobre bem imóvel de propriedade da União, entregue para exploração econômica por parte da Barrafor Veículos Ltda.

Na ementa da decisão combatida, inclusive, ficou consignada a "impossibilidade de, a teor do que dispõe o art. 34 do CTN, proceder-se à cobrança do tributo IPTU sobre quem não detém nem o domínio nem a posse sobre o referido bem”.

O Município recorrente sustentou que segundo as próprias declarações da Empresa, é ela quem, de fato, exerce o domínio útil - ou ao menos a posse - do imóvel em foco, não havendo, pela letra do comando legal transcrito, qualquer óbice a que a cobrança do IPTU e das taxas fundiárias sobre ela recaia.

Interposto ainda Recurso Especial da decisão, o Superior Tribunal de Justiça entendeu que o cessionário não pode ser taxado de contribuinte do IPTU, por não exercer nenhum direito de propriedade sobre o imóvel, bem como a jurisprudência de ambas as Turmas da Primeira Seção terem assentado o entendimento de que somente é contribuinte do IPTU o possuidor que tenha animus domini. 
A Procuradoria-Geral da República opinou pelo desprovimento do recurso, com base na jurisprudência do Supremo Tribunal Federal.

Este é, pois, o panorama sob o qual a questão foi posta à análise para a corte Constitucional, cabendo-lhe então enfrentar a matéria e definir sua interpretação, o que será objeto de análise no tópico a seguir.

\section{A PREMISSA UTILIZADA PELO SUPREMO TRIBUNAL FEDERAL COMO ESTABELECIMENTO DE NOVO PARADIGMA HERMENÊUTICO E A NECESSIDADE DE REVISÃO JURISPRUDENCIAL}

O Ministro Relator Edson Fachin (RE 601.720), ao iniciar seu voto, informou que, para deslinde do litígio constitucional, duas questões deveriam ser respondidas, quais sejam, a) Pode a pessoa cessionária do uso de imóvel pertencente à União figurar como sujeito passivo da obrigação tributária referente ao Imposto Predial e Territorial Urbano (IPTU)? e b) Pode a Municipalidade prever, instituir e arrecadar IPTU, em que a base impositiva seja imóvel de titularidade da União, ainda que o bem seja objeto de contrato administrativo de concessão de uso, assim como haja particular que utilize o imóvel com finalidade lucrativa?

Ao abordar a primeira questão, tece considerações a respeito da hipótese de incidência do IPTU, classificando-o como imposto real, direto, fiscal, progressivo e complexivo, dando destaque à definição do fato gerador regrada no art. 32 do CTN.

Neste ponto, objetiva que o CTN “autoriza a municipalidade a impor, mediante lei, o referido tributo em três situações diversas: a propriedade, o domínio útil e a posse a qualquer título."

O relator evoca ainda os arts. 109 e 110 do CTN, por tratarem serem tais institutos afetos ao direito civil e citando, por conseguinte, os arts. 1.196 e 1.228 do Código Civil, trazendo a sua decisão os conceitos de posse e propriedade, bem como de domínio útil para, mais uma vez mencionar o aspecto pessoal do tributo tal como previsto no art. 34 do CTN.

Após, volta-se à natureza jurídica da INFRAERO, de empresa pública, bem como que o Supremo já havia assentado a ela a extensão de imunidade tributária recíproca, na qualidade de prestadora de serviço público, no âmbito do ARE-RG 638.315, para, ao fim, se o contrato de concessão de uso de área aeroportuária, firmado entre empresa pública imune e 


\section{O JULGAMENTO DOS RES 594.015 E 601.720 E A REVISÃO JURISPRUDENCIAL A RESPEITO DA LEGITIMIDADE PASSIVA DO IPTU NA HIPÓTESE DE POSSUIDOR SEM \\ ANIMUS DOMINI}

sociedade empresária com finalidades lucrativas, possui o condão de tornar o cessionário sujeito passivo de obrigação tributária referente ao IPTU

Assim, o Relator reconhece ser majoritária a interpretação de que o art. 32 do CTN é limitada à posse que, per se, possa conduzir à propriedade, tendo em vista que é incompatível com a Constituição Federal de 1988 a eleição de meros detentores de terras públicas, isto é, desprovidos de posse ad usucapionem, como contribuintes de IPTU.

Por fim, destaca que a jurisprudência do Supremo Tribunal Federal já se manifestou no sentido de que a posse do concessionário de uso é precária e desdobrada, por conseguinte não é fato gerador do IPTU, concluindo, por fim, que se responde negativamente a ambos os quesitos formuladas no início do voto

O Ministro Gilmar Mendes, propõe a discussão da matéria, levantando a questão de que, embora não haja possibilidade de o município tributar essa atividade, por outro lado, ele é sobreonerado, porque tem, no âmbito de seus territórios, um serviço que traz carga, sujeira, gente, em suma, o oneraria demasiadamente.

Neste momento, o Relator do RE 594.015, Ministro Marco Aurélio intervém, destacando que no contrato de concessão, consta cláusula prevendo que a concessionária arcaria com os tributos, até mesmo o municipal, bem como, em ponto mais adiante do debate, de que o Código Tributário Nacional se refere ao uso a qualquer título, pedindo vistas do processo, ao fim, já que poderia levar ao plenário ambas os processos.

Com a retomada do julgamento, o Ministro Marco Aurélio destaca que o deslinde da questão passa por definir se a imunidade prevista na alínea “a” do inciso VI do artigo 150 da Constituição Federal alcança, ou não, bem imóvel de propriedade da União cedido a empresa privada que explora atividade econômica, considerando a questão de suma importância, porquanto vislumbrou potencial violação aos ditames da ordem econômica.

Destaca, tanto no voto-vista quanto voto de relator, que, pelo o $\S 3^{\circ}$ do art. 150 da Constituição Federal "nem mesmo as pessoas jurídicas do direito público, que exploram atividade econômica, gozam da imunidade, o que se dirá quanto ao particular”, e reconhecer a imunidade neste caso significaria afronta ao princípio da livre concorrência, versado no art. 170 da Constituição, por estar-se conferindo a pessoa jurídica de direito privado vantagem não existente para os concorrentes.

Neste ponto, o Ministro reconhece que a hipótese de incidência do Imposto Predial Territorial Urbano -IPTU não estaria limitada à propriedade do imóvel, incluindo o domínio 
útil e a posse do bem, bem como entendimento valeria para o contribuinte do tributo, que não se restringe ao proprietário do imóvel, alcançando tanto o titular do domínio útil quanto o possuidor a qualquer título.

Iniciada a votação, o Ministro Edson Fachin confirma seu voto (e explana sua divergência, já que os julgamentos se deram em conjunto), pelas razões explanadas, ratificando que, na forma da jurisprudência sedimentada, a conformação legislativa do Poder Executivo municipal está adstrita à posse que, per se, pode conduzir, ou possa conduzir à propriedade.

Com a continuidade da votação que sinalizava para o afastamento da imunidade, o Ministro Luís Roberto Barroso intervém para propor a modulação de efeitos da decisão, já que, em seu entender, estar-se-ia modificando a jurisprudência consolidada do Tribunal para “a incidência do tributo sobre a posse”, ou, como depois retifica, que o Supremo Tribunal Federal fixou entendimento no sentido da impossibilidade do detentor da posse, decorrente de contrato de concessão de uso, figurar no polo passivo da obrigação tributária

Entretanto, o Ministro Ricardo Lewandowski propõe que tal modulação seja analisada na eventualidade de oposição de Embargos Declaratórios, o que, a posteriori, é reconhecido como viável pelo Ministro Barroso, destacando a ausência na assentada de outros ministros e, como apontado pelo Ministro Celso de Mello, seriam necessários ao menos 08 (ministros) para tornar a modulação temporal eficaz.

E, ao fim, por maioria, conforme alhures explanado, ficaram definidas as seguintes teses:

Quanto ao RE 594.015, “A imunidade recíproca, prevista no art. 150, VI, a, da Constituição não se estende a empresa privada arrendatária de imóvel público, quando seja ela exploradora de atividade econômica com fins lucrativos. Nessa hipótese é constitucional a cobrança do IPTU pelo Município”.

Quanto ao RE 601.720, “Incide o IPTU, considerado imóvel de pessoa jurídica de direito público cedido a pessoa jurídica de direito privado, devedora do tributo”.

Após análise dos fundamentos que levaram o Supremo Tribunal Federal a tais teses, observa-se que o Tribunal adotou uma posição consequencialista, no sentido de que a premissa relevante para a tomada da decisão foi a suposição dos efeitos pragmáticos da decisão. 


\section{O JULGAMENTO DOS RES 594.015 E 601.720 E A REVISÃO JURISPRUDENCIAL A RESPEITO DA LEGITIMIDADE PASSIVA DO IPTU NA HIPÓTESE DE POSSUIDOR SEM \\ ANIMUS DOMINI}

No caso em espeque, o que preponderou foi a ideia de isonomia para a livre concorrência, princípio este sob o qual os arrendatários ou cessionários de bem público não estariam regidos caso fosse estendida a eles a regra de imunidade tributária recíproca.

Entretanto, não foi olvidada pelo Tribunal a dogmática tributária, no que diz respeito à não extensão da condição de sujeito passivo do IPTU ao detentor de posse precária, sobretudo pelos Ministros Edson Fachin e Luís Roberto Barroso. Para os julgadores, embora tenham divergido no mérito, há clara modificação da jurisprudência do Supremo Tribunal Federal.

Também nos votos do Ministro Marco Aurélio há clara consignação de que o art. 34 do CTN não limita a sujeição passiva à qualidade da posse, de modo que, segundo ele, seria contribuinte também o possuidor do imóvel a qualquer título, note-se, não apenas o cessionário.

A impressão que se depreende do acórdão é que as consequências de eventual superação jurisprudencial neste sentido foram sentidas por poucos Ministros, mormente o Ministro Barroso, que propôs a modulação de efeitos da decisão, o que, entretanto, ficou pendente para o julgamento dos Embargos que, efetivamente, foram opostos e, até a data de submissão deste artigo, não foram postos em pauta para julgamento.

É de se denotar que a hermenêutica constitucional tributária tem se voltado para a presunção de certos fins econômicos como fundamento para interpretação da regra matriz de incidência dos tributos.

Não se questionando a legitimidade constitucional de tal modelo, deve-se destacar, entretanto, a importância de que a atuação do intérprete passe também pela dogmática estabelecida na matéria, sob pena de que não se perceba que a repercussão fática da decisão seja muito maior que aquela previamente acreditada.

\section{CONCLUSÃO}

O Supremo Tribunal Federal, revisando jurisprudência anteriormente estabelecida, passa a admitir que o possuidor cessionário/arrendatário explorador de atividade econômica é contribuinte de IPTU, afastando a regra de imunidade tributária recíproca e, portanto, admitindo tal forma de posse como fato gerador apto a criar obrigação tributária. 
Porém, é de se questionar ainda se tal posse tem qualidade que a distinga de outras de caráter precário a ponto de haver coadunação entre somente ela e a hipótese de incidência do IPTU, ou ainda se, efetivamente, é a posse a qualquer título que gera a obrigação tributária.

Em outras palavras, a estabilidade criada na decisão que dirime a vexata quaestio a respeito da incidência de IPTU para possuidor cessionário, gera controvérsia no que pertine as demais formas de posse sem animus domini.

Isto porque, esta controvérsia, apesar de gerada pelo julgamento dos Recursos Extraordinários em comento e permear os acórdãos, não foi posta em xeque, e deve ser eventualmente esclarecida pelo plenário do Supremo Tribunal Federal, seja nos Embargos de Declaração opostos daquelas decisões, seja nas novas hipóteses que surgirem tendo por premissa a nova jurisprudência firmada.

O que não se afigura razoável, entretanto, é que das várias espécies de posse precária, liste-se algumas que seriam hipótese de incidência do IPTU, e outras que não atingiriam o núcleo da regra matriz de incidência, porquanto geraria severa insegurança jurídica ao intérprete e ao contribuinte, além distorcer as limitações basilares do IPTU.

\section{REFERÊNCIAS}

ALEXY, Robert. Constitucionalismo discursivo. Trad. Luís Afonso Heck. 4. ed. Porto Alegre: Livraria dos Advogados, 2015.

ATALIBA, Geraldo. Hipótese de incidência tributária. 7. ed. São Paulo: Malheiros, 2005. Sistema constitucional tributário brasileiro. São Paulo: RT, 1968.

ÁVILA, Humberto. Sistema constitucional tributário. São Paulo: Saraiva, 2012.

. Neoconstitucionalismo: entre a ciência do direito e o direito da ciência. Revista Eletrônica sobre Reforma do Estado (RERE), n. 17, Salvador, Instituto Brasileiro de Direito Público, jan.-mar., 2009. Disponível em $<$ http://www.direitodoestado.com/revista/REDE-17-JANEIRO-2009-

HUMBERTO\%20AVILA.pdf> . Acesso em: 20 ago.2016.

Teoria dos princípios: da definição à aplicação dos princípios jurídicos. 16. ed. São Paulo: Malheiros, 2015.

BALEEIRO, Aliomar. Direito tributário brasileiro. Atual. Misabel Abreu Machado Derzi. 13. ed. Rio de Janeiro: Forense, 2015. 
. Limitações constitucionais ao poder de tributar. Atual. Misabel Abreu Machado

Derzi. 8. ed. Rio de Janeiro: Forense, 2010.

. Uma introdução à ciência das finanças. 16. ed. Rio de Janeiro: Forense, 2003.

BARRETO, Aires Fernandino. ISS - Alguns limites constitucionais do critério espacial.

Revista Dialética de Direito Tributário. São Paulo, n. 208, p. 7-14, jun.2014.

BECKER, Alfredo Augusto. Teoria geral do direito tributário. São Paulo: Noeses, 2013.

BOBBIO, Norberto. A era dos direitos. Trad. Carlos Nelson Coutinho. Rio de Janeiro: Campus, 1992.

Teoria do ordenamento jurídico. 10. ed. Trad. Maria Celeste Cordeiro Leite dos Santos. Brasília: Editora UnB, 1999.

BORGES, José Souto Maior. Obrigação Tributária: uma introdução metodológica. 3. ed. São Paulo: Malheiros, 2015.

BRITO, Edvaldo. Aspectos constitucionais da tributação. In: As vertentes do direito constitucional contemporâneo. MARTINS, Ives Gandra (coord.). Rio de Janeiro: América Jurídica, 2002.

Direito tributário e constituição: estudos e pareceres. São Paulo: Atlas, 2016.

Reflexos jurídicos da atuação do estado no domínio econômico. São Paulo: Saraiva, 1982.

BUJANDA, Fernando Sainz de. Hacienda y Derecho. v. 1. Madrid: Instituto de Estudios Políticos, 1975.

BULOS, Uadi Lâmego. Curso de Direito Constitucional. 6a ed. São Paulo: Saraiva, 2011.

CARRAZZA, Roque Antônio. Curso de Direito Constitucional Tributário. 29. ed. São Paulo: Malheiros, 2013.

CARVALHO, Paulo de Barros. Curso de Direito Tributário. 27. ed. São Paulo: Saraiva, 2016.

Derivação e Positivação no Direito Tributário. São Paulo: Noeses, 2011.

Direito Tributário, Linguagem e Método. São Paulo: Noeses, 2008.

. Direito Tributário: fundamentos jurídicos da incidência. 3.ed. São Paulo: Saraiva, 2004.

COELHO, Sacha Calmon Navarro. Curso de Direito Tributário Brasileiro. Rio de Janeiro: Forense, 2010. 
COSTA, Regina Helena. Curso de Direito Tributário: Constituição e Código Tributário Nacional. 6. ed. São Paulo: Saraiva, 2016.

CUNHA JR., Dirley da. Curso de Direito Constitucional. 9. ed. Salvador: Jus Podivm, 2015.

FALCÃO, Amilcar da Araújo. Fato gerador da obrigação tributária. 7. ed. São Paulo: Noeses, 2013.

Introdução ao Direito Tributário. 5. ed. Rio de Janeiro: Forense, 1994.

FERRAZ Jr., Tércio Sampaio. Introdução ao Estudo do Direito: Técnica, decisão e dominação. 7. ed. São Paulo: Atlas, 2013.

GAMBA, Luisa Hickel. A imunidade tributária recíproca na jurisprudência do Supremo Tribunal Federal. Revista de Doutrina da $4^{\text {a }}$ Região, Porto Alegre, n. 56, out. 2013. Edição especial 25 anos da Constituição de 1988. (Grandes temas do Brasil contemporâneo). Disponível em: <http://revistadoutrina.trf4.jus.br/artigos/edicao056/Luisa_Gamba.html> Acesso em: 05 mar. 2017.

HESSE, Konrad. A força normativa da constituição. Tradução de Gilmar Ferreira Mendes. Porto Alegre: Safe, 1991.

MACHADO, Hugo de Brito. Curso de Direito Tributário. 36. ed. São Paulo: Malheiros, 2015.

OLIVEIRA, Ricardo Mariz de. Fundamentos do Imposto de Renda. São Paulo: Quartier Latin, 2008.

SCHOUERI, Luís Eduardo. Direito Tributário. 6. ed. São Paulo: Saraiva: 2016.

. Tributação e Liberdade. In: PIRES, Adilson Rodrigues e TÔRRES, Heleno Taveira (Coords.). Estudos em Homenagem ao Professor Ricardo Lobo Torres. Rio de Janeiro: Renovar, 2006.

SILVA, José Afonso da. Aplicabilidade das Normas Constitucionais. 8. Ed. São Paulo: Malheiros, 2015.

. Curso de Direito Constitucional Positivo. São Paulo: Malheiros, 2006.

TORRES, Ricardo Lobo. A idéia de liberdade no estado patrimonial e no estado fiscal. Rio de Janeiro: Renovar, 1991.

VELLOSO, Andrei Pitten. Constituição Tributária Interpretada. 2. ed. Porto Alegre: Livraria do Advogado, 2012. 